\title{
EVALUATION OF PAN BREAD AND PIES MADE BY PARTIAL SUBSTITUTION WITH DATES SYRUP (DIBS)
}

\author{
BEDEIR, S.H.
}

Food Tech. Res. Inst., ARC, Giza, Egypt.

(Manuscript received 2 June 2014)

\begin{abstract}
Date syrup contains about $80 \%$ of invert sugars . This syrup is considered as an excellent source of sugar, dietary fibers, minerals and trace elements. Date syrup addition in bread processing was found to cause an increment in weight and volume of both resulted pan bread and pies. It, also, improves texture of bakery products. When date syrup was utilized as a substitute of sucrose in the bakery products formula, crumb characteristics (such as aroma and taste) are markedly improved with increasing the concentration of date syrup. The object of this study was conducted to reduce the loss of wastages of the dates (30\%) by processing and preserving it in the form of date syrup, which led to maximizing the value addition of date's crop in Egypt, and added to total National income. In Egypt, only $70 \%$ of the harvested dates are utilized. Partial replacement of sucrose by $10-50 \%$ date syrup (dibs) was studied for both pan bread and pies prepared by straight dough procedure.

Good quality pan bread and pies was obtained in the present work by a partial replacement of sucrose with 10, 20 and $30 \%$ date syrup, respectively. These substitutions significantly retarded firming of the bread crumb after 3 days of storage. Date syrup treatments showed an improvement in all quality characteristics, except that of crumb color, which was adversely affected by the addition of high proportion of date syrup. Addition of date syrup, also, improved the total gas production, and delayed the starch gelatinization (reterogradation).

Addition of date syrup to the dough, prolonged the shelf life of pan bread and pies. High concentrations (40 and $50 \%$ ) of added date syrup resulted in a poor effect on the gassing and handling properties of resulted dough.

The obtained preliminary results in the present work indicated that dates syrup is a promising ingredient for use in some bakery products. Sucrose can be partially replaced by date syrup, where the sensory properties of both pan and pies are markedly improved.

Key words: Date syrup, pan bread, pies, Gas retention, Staling, Sensory evaluation.
\end{abstract}

\section{INTRODUCTION}

Dates (Phoenix dactylifera) considered a major fruit crop in Egypt. It has played an important role in the economic and social lives of the Egyptian people. Less than $70 \%$ of the produced crop is processed and substantial quantities are lost because of pest infestation and lack of efficient marketing. According to (FAO, 2007), Egypt became a major date-producing country in the world since 2006, the estimated 
number of palm trees in Egypt is over than 20 million trees, occupy an area of 140000 hectare and its annual production was estimated to be $1,120,000$ metric Tons of dates which represented about $15 \%$ of the total world production (Fig. 1). The world production has tripled increased during the last 30 years from 3,909,201 metric Tons in 1977 to $12,020,540$ metric tons in 2007 (FAO, 2007).

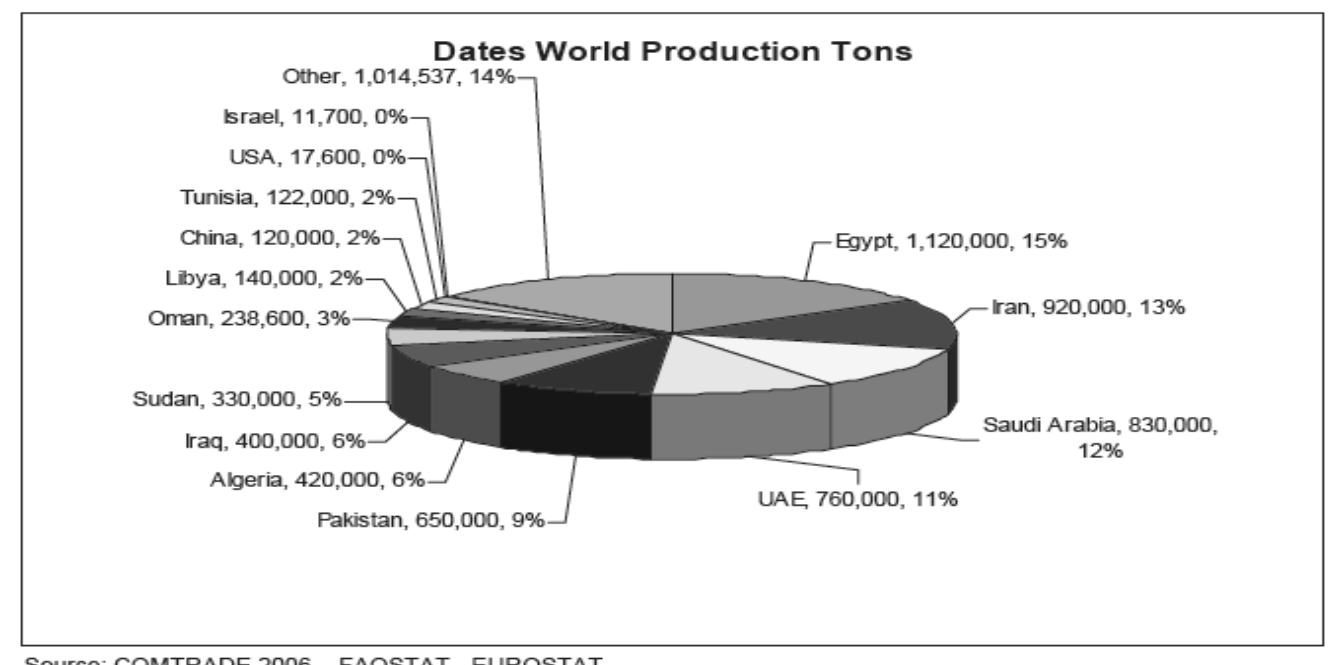

Fig. 1. Dates World Production (Tons)

Dates fruits considered a high nutritious food, it is a rich source in carbohydrates (70 - $80 \%$ ) comprising mainly of sugars and dietary fibers, which making it one of the most nourishing natural foods available to the human. Dates are also a good source of some vitamins $\left(A, B_{1}, B_{3}\right.$, and $\left.C\right)$ and macro-elements, such as phosphorus, iron, potassium and calcium (Biglari et. al., 2009).

Fermentable sugars in bakery products dough are essential for yeast as a source of energy, where as residual sugars in baked loaves and pies play an important role in determining its eating characteristics and also affected the flavor and shelf life of both resulted pan bread and pies (Iqbal et. al., 2011).

Dates also being exceptionally rich in potassium and extremely low in sodium; it is a desirable food for hypertensive persons who are advised to consume low sodium diets. Besides the nutritional value, dates are rich in phenolics and flavonoid compounds (Al-Farsi, et. al., 2007), which have been shown to possess such biological benefits for human health.

Dates processing are still following many of the time-honored methods of production and have not yet caught up with other modern agricultural industries (AlHooti et. al., 2002). 
Date syrup; locally named dibs, is the main and general by-product dates is used in foodstuffs manufacturing, such as: jams, marmalades, concentrated beverages, chocolates, ice cream, confectioneries, honey, and bakery products (Sidhu et. al., 2003). Dibs are produced in two different ways:-

1- At domestic or village by extraction and boiling down of dates juice.

2- On a semi or full industries scale; the process is mainly consisting of extraction.

The economic of the dates industry has been improved through the development of products and/or technologies that allow new markets to be exploited, through increases in efficiency and through the improvement quality of the final product. Although, the importance and the high yield of dates in Egypt.

Therefore, the current study was performed to try producing nutritious high quality of pan bread and pies sweetened with date syrup (dibs), and a comparative estimation between them was done in relative to the control one.

\section{MATERIALS AND METHODS}

\section{Materials}

Wheat flour (72\% ext.) was obtained from Ebn EL-Khatab Mill Company - 6hㅡ October City. Other ingredients: shortening, activated compressed dried yeast, salt, dry milk, sugar and agatti dates, were purchased from local market. A straight dough method for pan bread and pies production was carried out according to the method described by AACC. (2004). Tables (1, and 2) listed the formulas ingredients that were used in preparing the control sample, and other treatments which involved a partial sucrose substitution $(10,20,30,40$, and 50\%) with date syrup $(1.8,3.6,5,4$, $7,2,9,0 \%$ for pan bread, and 3.0, 6.0, 9.0, 12.0, $15.0 \%$ for pies formulas respectively).

\section{Methods}

\section{Chemical and physico - analysis of wheat flour (72\% ext.)and date syrup:-}

Wheat flour (72\% ext.) and date syrup were analyzed for moisture, protein, ash, fiber, fat, minerals, vitamins, fructose and carbohydrates (by difference). Sedimentation, falling number, water retention capacity and gluten were also estimated according to the methods described in AACC (2004).

\section{Preparation of date syrup:-}

It was prepared according Awan and Farkhanda (1999) as follows:

Agatti date cultivar fruits were cultivated and obtained from Siwa were soaked for $5 \mathrm{~min}$ in water, then grinding and extracted the syrup by cooking in water (1:3, 
$w \backslash w)$ at $70-75{ }^{8} \mathrm{C}$ in an open pan for $40 \mathrm{~min}$. The slurry was then filtrate through a cloth filter, concentrated by boiling to $70-75 \%$ Brix. Then the resulted syrup was collected as a stock material for further proceeding.

\section{Dough ingredients used in investigation were as follow:-}

Wheat flour (72\% ext.), date syrup was used at levels (10 - $50 \%)$ of sucrose amount, date syrup contained $80 \%$ total soluble solids which contain $70 \%$ fructose which equal $56 \mathrm{gm}$ fructose / $100 \mathrm{gm}$ date syrup, sucrose, salt, shortening, dry milk, yeast and water variable amount. Water was added up to $55.8 \%$, and $30 \%$ for both control of pan bread and pies formula respectively and for the 10, 20, 30, 40, and 50 $\%$ date syrup substitution, water was reduced as illustrated in (Table 1, and 2). Dough samples were fermented to $60 \mathrm{~min}$ at ambient temperature of (35 \pm 2

\section{Rheological dough parameters:-}

Rheological properties of the control and other (5) treatments (containing 10, $20,30,40$, and $50 \%$ date syrup as sugar replacement) were carried out by using farinograph and extinsograph. Total gas production and viscosity of wheat flour and date syrup mixtures were tested by using visco - amylograph. Gluten (wet and dry) and gluten index were determined according to AACC (2004) by using Glutomatic (2002) instrument.

\section{Physical properties of prepared pan bread and pies:-}

The following physical properties were carried out according to the methods of AACC (2004):-

1- Weight was recorded by using sensitive balance $(0.1 \mathrm{gm})$.

2- Volume was determined by rape seeds displacement method.

3- Specific volume was calculated by using the following equation :-

$$
\text { Specific volume }=\quad \frac{\text { Volume }(\mathrm{cm} 3)}{\text { Weight }(\mathrm{gm})}
$$

4- Sedimentation test.

\section{Baking test:-}

Samples of both pan bread and pies dough were prepared by straight dough procedure according to method described by AACC (2004) and finally dough was proofed at $40 \quad \mathrm{C}$ and $80 \%$ relative humidity until the dough attained the height of $11 \mathrm{~cm}$ and $4 \mathrm{~cm}$ for both pan bread and pies, respectively.

\section{Staling studies (compressibility):-}

After pan bread and pie samples being cooled for three hour, samples were wrapped in polypropylene packages, sealed, and stored for 1,2 and 3 days at $25{ }^{8} \mathrm{C}$. 
Staling evaluation (compressibility) was measured by using texture machine with a cylindrical disk model (Texfol - Nxt - Texture analyzer - UK). Percentage change in compressibility as described in AACC (2002) calculated from the following :-

$\%$ change in compressibility $=$

$$
\frac{\mathrm{C} 1-\mathrm{C} 2}{\mathrm{C} 1}
$$

Where:-

$$
\begin{aligned}
& \mathrm{C} 1=\text { the compressibility at zero time in }(\mathrm{mm}) \\
& \mathrm{C} 2=\text { the compressibility after period of storage in }(\mathrm{mm})
\end{aligned}
$$

\section{Sensory evaluation:-}

Samples were submitted to sensory evaluation by ten well trained panelists from Food Technology Research Institute (FTRI) staff through assigning scores for various external and internal quality parameters.

\section{Statistical analysis:-}

Obtained results of sensory evaluation were statistically analyzed by one-way analysis of variance and test significant differences tests (ANOVA) were carried out according to the method described by Snedecor and Cochran 1980.

\section{RESULTS AND DISCUSSION}

\section{Physico - Chemical analysis of wheat flour (72\% ext.) and Date syrup:-}

\section{Wheat flour (72\% ext.):-}

Results from Table (3) showed that wheat flour ( $72 \%$ ext.) contained moisture $(13.17 \%)$, protein $(12.11 \%)$, ash $(0.54 \%)$, fiber $(0.13 \%)$, fat $(1.04 \%)$ and total carbohydrates (73.01\%). Similar results were obtained by Bedeir, (2004) who reported that wheat flour $(72 \%$ ext.) samples from different sources contained moisture, protein , fat , ash , fiber and total carbohydrates ranged from : 10.25 $13.59,9.96-13.11,0.98-1.12,0.51-0.64,0.12-0.23$, and $73.12-78.23 \%$, respectively. Wheat flour ( $72 \%$ ext.), also, contained $25.72 \%$ wet gluten, 93.1 gluten index. Its sedimentation value and falling number were $34 \mathrm{ml}$, and $346 \mathrm{sec}$, respectively. These results are in agreement with those obtained by Nedif et. al., (2011).

\section{Date syrup :-}

Obtained results in Table (3) indicate that date syrup (dibs) contained moisture $(20.08 \%)$, protein $(2.18 \%)$, ash (3.54 \%), fiber $(0.77 \%)$, fat $(0.15 \%)$ and total carbohydrates $(71.28 \%)$. These results are correlated with the finding of AL- 
Hooti et. al., (2002) who reported that the dried date contained moisture ( 7- $12 \%$ ), protein( $1.7-3.9 \%)$, fat $(0.1-1.2 \%)$, total carbohydrates $(72.9-77.6 \%)$, fiber $(0.5-2.7 \%)$, and ash $(2.8-5.5 \%)$. Similar results were found by Awan and Farkhanda (1999) who showed that the date syrup characteristics were: moisture $18.8 \%$ - total sugars $78.2 \%-\mathrm{pH} 4.69$ and water activity 0.66 .

\section{Nutritional content of date syrup (dibs) :-}

As recorded in Table (4), it could be also observed that date syrup (dibs) contained a fair amount (mg/100g date Dibs, on dry basis) of $\mathrm{Na}$ (15.85), Zn (6.9) and Fe (4.541). It also contained a reasonable amount ( $\mathrm{mg} / 100 \mathrm{~g}$ dry matter) of $\mathrm{Cu}$ (0.731) and Mn (0.425). From the obtained data (Table 4), it could be also illustrated that date syrup (dibs) contained a considerable small amounts (mg /100 g dry matter) of L-ascorbic acid, (0.981), thiamin; Vit.B1 (0.143), riboflavin; (0.0678) and niacin; Vit.B3 (1.802). Chaiya and Pongsa (2011) mentioned that adding date syrup to both pan bread and pies increasing the content of minerals specially $\mathrm{Ca}, \mathrm{K}, \mathrm{P}, \mathrm{M}, \mathrm{Z}$ and $\mathrm{Fe}$. Thereupon, date dibs characterized with a high nutritional value with respect to their contents of the determined elements and vitamins as well as with a good healthy biological function for hypertensive persons as they contained an exceptional high content in potassium with an extremely low content in sodium. These results are in accordance with those reported by Al-Hooti et. al., (2002).

\section{Rheological parameters:-}

\section{1 - Farinograph, and Extinxograph :-}

Presented data in Table (5 and Fig 2) showed that water absorption was significantly affected by the addition of date syrup as a partial sucrose replacement with a different ratio in both pan bread and pies dough samples. Increasing date syrup replacement level resulted in a consistent decrease in the water absorption and dough stability time, while dough mixing time and tolerance index increased. Hussin (2008) reported that addition of date syrup to wheat flour led to a decrease in the water absorption and dough stability time, and the dough mixing time was increased.

Obtained data (Table 5 and Fig 3) indicated that the partial replacement of sugar by date syrup modified the bread and pie dough properties which led to cause a marked decrease in elasticity, proportional number and energy values compared with control sample. The resulted data showed also that extensibility values were increased by date syrup addition, especially at the higher levels (40 - 50\%).

\section{2 - Visco - Amylograph :-}

Numerous evidences indicating the beneficial effect of date syrup on gluten development in the dough, were reported by Ahmed and Ramaswamy, (2006). 
At the higher replacement of date syrup levels, the dough becomes sticky and difficult to handle. Table (6) show that dough treated with date syrup produce a remarkable increase in the maximum viscosity as a result of an adverse effect on the functionality of the blends of date syrup and wheat flour in bread and pies making.

Spies and Hoseny (1982) mentioned that increase in the pasting temperature means retardation in the starch gelatinization process and has a beneficial effect on the functionality of the starch in the bread system. On the other hand, gelatinization temperature was affected by the substitution of date syrup for wheat flour, and reterogradation point (set - back).

Results showed also that as the replacement levels of date syrup increased, the retarding effect on starch gelatinization (Ahmed and Ramaswamy, 2006) was indicated.

\section{3 - Sedimentation value and Gas production:-}

High values for sedimentation test were shown in Table (7) for samples fortified with 40 and $50 \%$ date syrup (46.8 and $53.6 \mathrm{ml}$ respectively), compared with the control $(34 \mathrm{ml})$. This conclusions are in agreement with Kitterman and Barmore (1999) who suggested that sedimentation test reflect difference in both protein content,gluten quality, insoluble proteins and sugar which are the factors largely responsible for sedimentation. AL-Zubaydi etal.,(2003) suggested that wheat flour containing sedimentation value ranging between 20 and $49 \mathrm{ml}$ could be considered suitable for making either cakes, pan bread or pies.

As shown in Table (7), which represents the gas production in the tested samples, the highest gas production values during fermentation, which extended to 180 min., were achieved by the 10 and $20 \%$ date syrup replacement.

The markedly low gas production recorded for $40 \%$ and $50 \%$ added date syrup compared with other dough, with regard to total gas retention, it is clear that the optimum date syrup replacement for gas production properties was between 10, and 20\%. These results are in agreement with the finding reported by Azza (1997), who revealed that higher sugar concentration reduced the rate and amount of gas production in fermentation dough. The partial replacement of sugar by the date syrup (10 - 30\%) marked an improvement in both gas production and retention. Therefore, it could be concluded that date syrup may be used as a good substitute for sugar in bakery products making.

\section{Physical prorerties of pan bread and pies:-}

Adding date syrup with a different ratio caused a substantial increase in the volume and specific volume of finished products (pan bread or pies) as shown in Table (8). Volume was sharply increased at (30\%) date syrup concentration, but it 
was markedly decreases above this level as a result of the impact of the higher concentration which reduced the rate and amount of gas production in fermented dough. Weight of resulted pan bread and pies showed a substantial increase as compared to control sample. This might be attributed to the hygroscopic nature of invert sugars, proteins, and pectic substances, which are present in the date syrup dough formula. The effect of various date syrups on the experimental pan bread and pies was studied by AL-Zubaydi, et. al., (2003), who reported that date syrups were found to cause a substantial increase in the weight and volume of loaves. Hussin (2008) found that adding date syrup (dibs) affected physical properties of both pan bread and pies.

\section{Baking parameters:-}

Addition of date syrup had significantly affect dough mixing time (Table 5 and Fig 2) which varies between $1 \mathrm{~min}$ for control sample and $4 \mathrm{~min}$ for $50 \%$ dibs treatment. On the other hand significant difference could be detected (Fig 2), in the final proof time as a result of adding date syrup. It is clearly evident from the test baking results (Table 8 ) that 10,20 and $30 \%$ dibs treatment increase volume, weight and specific volume while, increasing the date syrup replacement levels to 40 and 50 $\%$ produced a loaf with physical properties much inferior to those of control sample.

\section{Sensory Characteristics of pan bread and pies}

\section{1 - External properties:-}

The external and internal characteristics of the tested pan bread and pies were sensory estimated as a functional of dibs utilization $(10-50 \%)$ as illustrated in Table (9). It was found that there was no significant difference with respect to symmetry and general appearance properties among the samples of pan bread and pies containing up to $40 \%$ date syrup, and the corresponding control sample. On contrary, $50 \%$ date syrup in pan bread and pies were completely significant different than the control sample.

Crust color values of pan bread samples were decreased due to date syrup addition, with a significant difference started at $20 \%$ date syrup in both pan bread and pies.

Nearly all sugars in date syrup are invert sugar (Sidhu et. al., 2003) and therefore they were expected to play a major role in the browning process of crust. On the other hand, both bakery products containing 30 and $40 \%$ date syrup were significantly different than the volume of the control sample and the other bakery products samples. 


\section{2 - Internal properties:-}

Specified ratio of date syrup (up to 10 , and $20 \%$ ) in both pan bread and pies respectively, significantly affected the crumb color, texture, and taste properties with a down word pattern. Crumb grain of pan bread samples was enhanced due to addition of 10 and $20 \%$ date syrup, whereas the other addition ratios showed lower values. The decrement pattern could be noticed in crumb grain property of pie samples. The odor of pan bread samples were not significantly differed in samples (pan bread and pies) treated with date syrup and the control sample. On contrary, the pie samples were vice versa.

In general, the overall acceptability of each tested samples in both pan bread and pies was significantly differed than control sample. Date syrup caused an improvement in texture (crumb) of pan bread and pies over the control sample, but other crumb characteristics, including taste, colour, grain, and aroma, were adversely affected by the addition of date syrup. Table (8) indicated that bread contained $10-20 \%$ date syrup was similar to control sample in all quality characteristics expect crust color, which was affected by addition of date syrup.

\section{Bread staling (Compressibility):-}

The compressibility results (Tables 10 and 11 ) illustrated that control sample showed a considerable decrease in the compressibility of pan bread and pies during storage. On contrary, samples substituted with date syrup showed a remarkable increase, indicating a marked retarding effect of date syrup on bread crumb firming after three days storage .

Date syrup substituted in pan bread and pies samples had a higher compressibility values for up to 2 and 3 days of storage at $25 \mathrm{C}$ compared with control sample.

The retarding effect of date syrup on bread and pies stalling may be attributed to high levels of fructose in date syrup (37.21\%) which aiding the retention of moisture in bread and pies, or to complex formation from one or more component of date syrup and starch. The complex formed may interfere with the starch retrogradation or crystallization (AL - Saidy et. al.,1999) .

Substitution of $10,20 \%$ and $30 \%$ date syrup in the bread formula significantly retarded firming of the bread crumb after 3 days storage. Date syrup also prolonged the shelf life of bread and pies through increasing their freshness.

Ziemke (1977) found that concentrated dates syrup had a multifunctional in a full range of baked products. It acts an important role in flavoring and sweetening and as an anti-staling agent. Shelf - life of resulted bread loaves and pies improved by the partial replacement of sugar with date syrup in bread formula, similar results with 
other date syrup products were reported by Al-Zubaydi et. al. (2003) who found that addition of date syrup increased the shelf life of the experimental bread and pies. They also indicated that baked products made with suitable percentage of date syrup retained moisture and freshness due to the moisture - holding properties of fructose.

Table 1. Pan bread formula

\begin{tabular}{|c|c|c|c|c|c|c|}
\hline \multirow{2}{*}{\multicolumn{2}{|c|}{}} & \multicolumn{5}{c|}{ Date syrup (Dibs) \% } \\
\cline { 3 - 7 } Ingredient (\%) & $10 \%$ & $20 \%$ & $30 \%$ & $40 \%$ & $50 \%$ \\
\hline Flour 72\% & $100 *$ & 100 & 100 & 100 & 100 & 100 \\
\hline Sugar (gm) & 15 & 1.5 & 3.0 & 4.5 & 6.0 & 7.5 \\
\hline Dibs (ml) & - & 1.8 & 3.6 & 5.4 & 7.2 & 9.0 \\
\hline Residual sugar (gm) & - & 13.5 & 12.0 & 10.5 & 9.0 & 7.5 \\
\hline Salt & 1.0 & 1.0 & 1.0 & 1.0 & 1.0 & 1.0 \\
\hline Shortening & 1.5 & 1.5 & 1.5 & 1.5 & 1.5 & 1.5 \\
\hline Yeast & 1.5 & 1.5 & 1.5 & 1.5 & 1.5 & 1.5 \\
\hline Water & 55.8 & 54.9 & 54.1 & 53.2 & 52.4 & 51.6 \\
\hline
\end{tabular}

*It was prepared according to AACC (2004)

Table 2. Pies formula

\begin{tabular}{|c|c|c|c|c|c|c|}
\hline \multirow{2}{*}{\multicolumn{2}{|c|}{ Ingredient (\%) }} & \multicolumn{5}{c|}{ Date syrup (Dibs) \% } \\
\cline { 3 - 7 } & & $10 \%$ & $20 \%$ & $30 \%$ & $40 \%$ & $50 \%$ \\
\hline Flour 72\% & $100 *$ & 100 & 100 & 100 & 100 & 100 \\
\hline Sugar (gm) & 25 & 2.5 & 5.0 & 7.5 & 10.0 & 12.5 \\
\hline Dibs (ml) & - & 3.0 & 6.0 & 9.0 & 12.0 & 15.0 \\
\hline Residual sugar (gm) & - & 22.5 & 20.0 & 17.5 & 15.0 & 12.5 \\
\hline Salt & 1.0 & 1.0 & 1.0 & 1.0 & 1.0 & 1.0 \\
\hline Dry milk & 3.0 & 3.0 & 3.0 & 3.0 & 3.0 & 3.0 \\
\hline Shortening & 10 & 10 & 10 & 10 & 10 & 10 \\
\hline Yeast & 1.5 & 1.5 & 1.5 & 1.5 & 1.5 & 1.5 \\
\hline Water & 30 & 25.0 & 24.0 & 22.5 & 21.0 & 20.0 \\
\hline
\end{tabular}

*It was prepared according to AACC (2004) 
Table 3. Physico - Chemical analysis of wheat flour $72 \%$ ext. and date syrup (dibs)

\begin{tabular}{|c|c|c|}
\hline Analysis & Wheat flour & Date syrup \\
\hline Moisture \% & 13.17 & 20.08 \\
\hline Protein \% & 12.11 & 2.18 \\
\hline Ash \% & 0.54 & 3.54 \\
\hline Fiber \% & 0.13 & 0.77 \\
\hline Fat \% & 1.04 & 0.15 \\
\hline *arbohydrates \% & 73.01 & 73.28 \\
\hline Fructose \% & - & 37.21 \\
\hline Gluten \% & 25.72 & - \\
\hline Gluten - Index & 93.1 & - \\
\hline Sedimentation(ml) & 34.0 & - \\
\hline Falling number & 346.0 & - \\
\hline Liquefaction number & 20.27 & - \\
\hline
\end{tabular}

*By difference.

Table 4. Nutritional content of date syrup (Dibs)

\begin{tabular}{|c|c|}
\hline Macro - Elements $(\mathrm{mg} / 100 \mathrm{~g})$ & Amounts \\
\hline $\mathrm{P}$ & 131.75 \\
\hline $\mathrm{Ca}$ & 64.85 \\
\hline K & 779.05 \\
\hline $\mathrm{Mg}$ & 49.8 \\
\hline $\mathrm{Na}$ & 15.85 \\
\hline $\begin{array}{l}\text { Micro - Elements } \\
(\mathrm{mg} / 100 \mathrm{~g})\end{array}$ & Amounts \\
\hline $\mathrm{Fe}$ & 4.541 \\
\hline $\mathrm{Cu}$ & 0.731 \\
\hline $\mathrm{Zn}$ & 6.90 \\
\hline $\mathrm{Mn}$ & 0.425 \\
\hline Vitamins & Amounts \\
\hline$C(\mathrm{mg} / 100 \mathrm{~g})$ & 0.981 \\
\hline A (IU) & 1921 \\
\hline$B_{1}(\mathrm{mg} / 100 \mathrm{~g})$ & 0.141 \\
\hline$B_{2}(m g / 100 g)$ & 0.0675 \\
\hline $\mathrm{B}_{3}(\mathrm{mg} / 100 \mathrm{~g})$ & 1.802 \\
\hline
\end{tabular}


Table 5. Effect of adding date syrup on farinograph and extinsograph parameters

\begin{tabular}{|c|c|c|c|c|c|c|c|c|}
\hline $\begin{array}{c}\text { Date } \\
\text { syrup } \\
(\%) \text { in } \\
\text { dough }\end{array}$ & Water & $\begin{array}{c}\text { Dough } \\
\text { absorption } \\
\text { mixing time } \\
(\mathrm{min})\end{array}$ & $\begin{array}{c}\text { Dough } \\
\text { stability } \\
(\mathrm{min})\end{array}$ & $\begin{array}{c}\text { Tolerance } \\
\text { index(BU) }\end{array}$ & $\begin{array}{c}\text { Elasticity } \\
(B U)\end{array}$ & $\begin{array}{c}\text { Extensibility } \\
(\mathrm{mm})\end{array}$ & $\begin{array}{c}\text { Proportional } \\
\text { Number }\end{array}$ & $\begin{array}{c}\text { Energy } \\
\left(\mathrm{cm}^{2}\right)\end{array}$ \\
\hline $\begin{array}{c}* \text { Contro } \\
\text { I }\end{array}$ & 60.0 & 1.0 & 6.5 & 85 & 560 & 75 & 7.5 & 43.1 \\
\hline $10 \%$ & 56.5 & 1.5 & 5.5 & 90 & 520 & 80 & 6.5 & 39.6 \\
\hline $20 \%$ & 54.9 & 2.0 & 4.5 & 100 & 500 & 85 & 5.9 & 36.9 \\
\hline $30 \%$ & 53.3 & 2.0 & 4.5 & 105 & 490 & 90 & 5.4 & 32.6 \\
\hline $40 \%$ & 52.2 & 2.5 & 4.0 & 105 & 440 & 95 & 4.6 & 28.3 \\
\hline $50 \%$ & 50.1 & 3.5 & 3.5 & 110 & 425 & 95 & 4.5 & 27.2 \\
\hline
\end{tabular}

*Wheat flour (72\% ext.)

Table 6. Effect of adding date syrup on the dough viscosity, and reterogradation point

\begin{tabular}{|c|c|c|c|c|c|c|}
\hline \multicolumn{1}{|c|}{ (set - back) } \\
\begin{tabular}{|c|c|c|c|c|} 
Date syrup \\
$\begin{array}{c}\text { (\%) in } \\
\text { dough }\end{array}$
\end{tabular} & $\begin{array}{c}\text { Transsion } \\
\text { point ( C) }\end{array}$ & $\begin{array}{c}\text { Maximum } \\
\text { Viscosity(BU) }\end{array}$ & $\begin{array}{c}\text { Temp. at max. } \\
\text { viscosity( C) }\end{array}$ & $\begin{array}{c}\text { Viscosity } \\
\text { at }(95 \\
\text { C) }\end{array}$ & $\begin{array}{c}\text { Viscosity } \\
\text { at } \\
(50 \quad \text { C) }\end{array}$ & $\begin{array}{c}\text { Set - } \\
\text { back (BU) }\end{array}$ \\
\hline $\begin{array}{c}* \text { Control } \\
10 \%\end{array}$ & 58.5 & 380 & 86.5 & 570 & 610 & 230 \\
\hline $20 \%$ & 62.0 & 435 & 88.0 & 570 & 625 & 190 \\
\hline $30 \%$ & 70.5 & 490 & 90.0 & 595 & 650 & 160 \\
\hline $40 \%$ & 74.0 & 545 & 91.5 & 605 & 690 & 145 \\
\hline $50 \%$ & 76.5 & 600 & 92.0 & 625 & 725 & 125 \\
\hline
\end{tabular}

*Wheat flour ( $72 \%$ ext.)

Table 7. Sedimentation value and Gas production of pan bread, and pies.

\begin{tabular}{|c|c|c|}
\hline $\begin{array}{c}\text { Date syrup } \\
(\%) \text { in dough }\end{array}$ & Sedimentation value $(\mathrm{ml})$ & Gas production $(\mathrm{ml})$ \\
\hline *Control & 34.0 & 106.5 \\
\hline 10 & 36.4 & 189.9 \\
\hline 20 & 39.9 & 196.5 \\
\hline 30 & 42.7 & 125.6 \\
\hline 40 & 46.8 & 99.8 \\
\hline 50 & 53.6 & 87.5 \\
\hline
\end{tabular}

*Wheat flour (72\% ext.) 


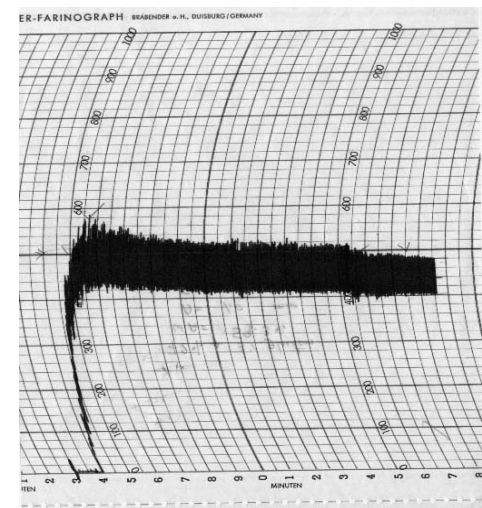

Control

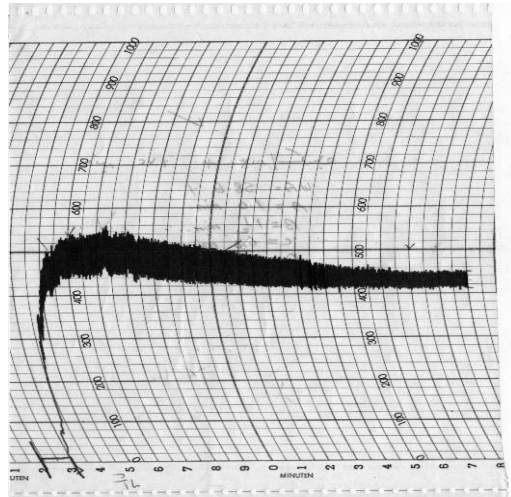

$20 \%$ date syrup

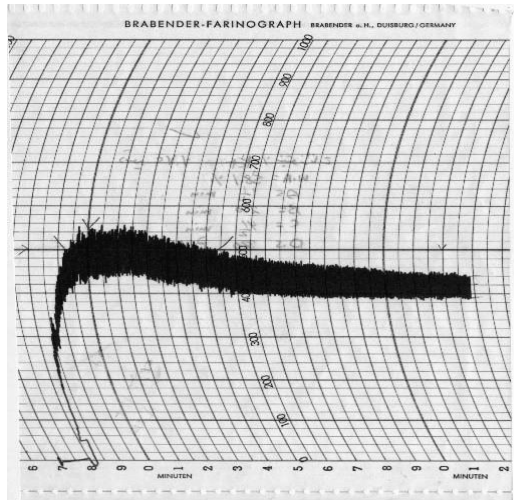

$40 \%$ date syrup

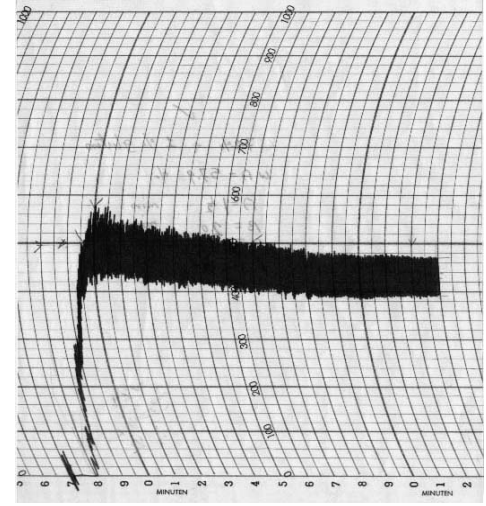

$10 \%$ date syrup

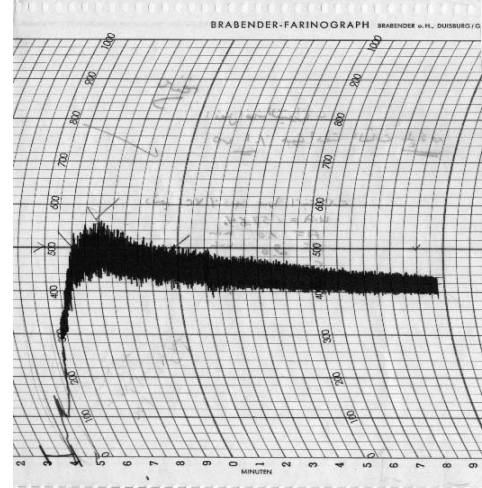

$30 \%$ date syrup

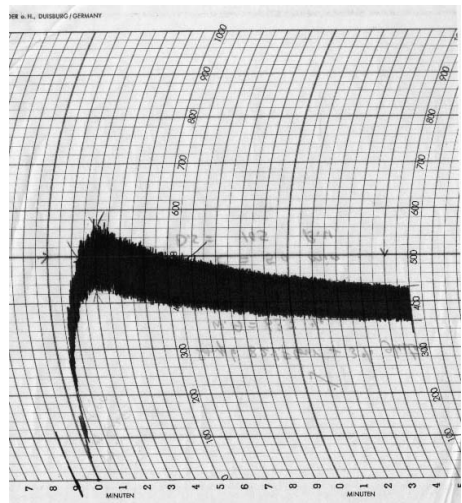

$50 \%$ date syrup

Fig 2. Farinograms of the tested formulas 


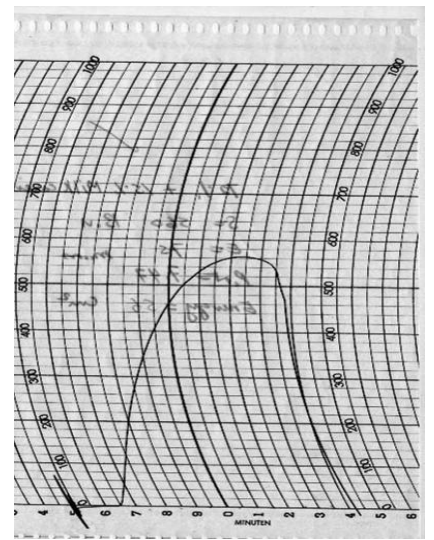

Control

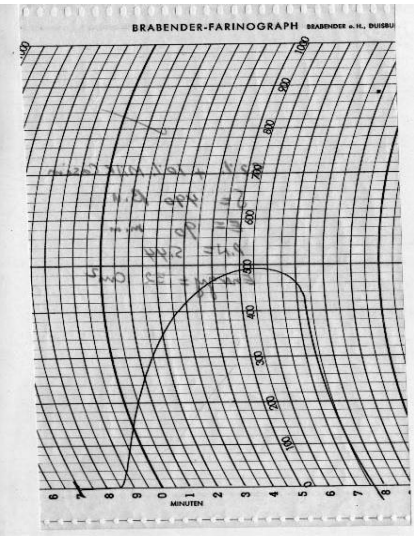

$20 \%$ date syrup

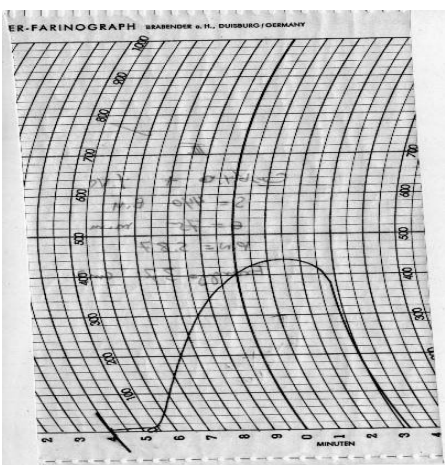

$40 \%$ date syrup

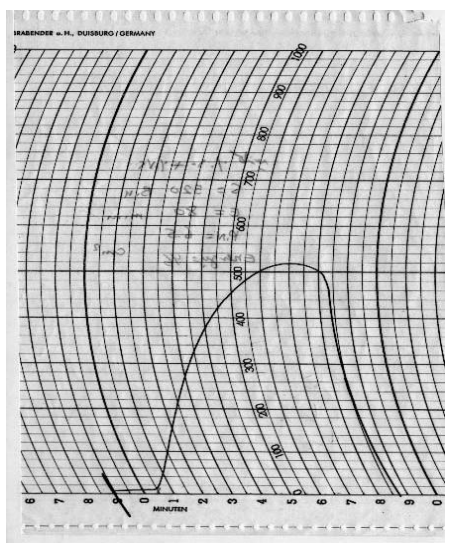

$10 \%$ date syrup

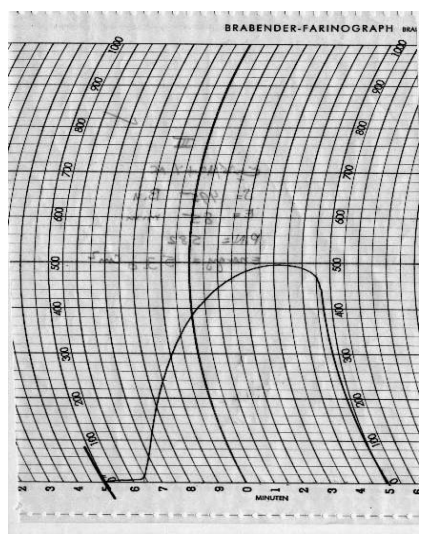

$30 \%$ date syrup

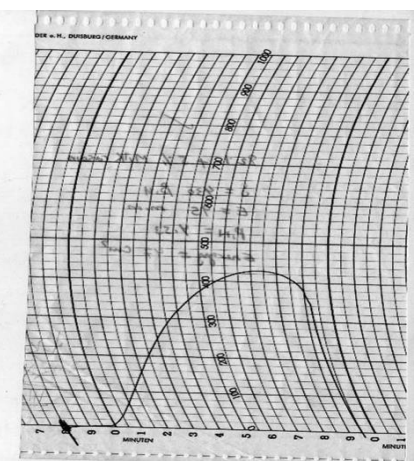

$50 \%$ date syrup

Fig 3. Extensograms of the tested formulas 
Table 8. Effect of adding date syrup on the physical properties of pan bread and pies.

\begin{tabular}{|c|c|c|c|c|}
\hline $\begin{array}{l}\text { Date syrup } \\
\text { (dibs \%) }\end{array}$ & Height (cm) & Weight (g) & Volume $\left(\mathrm{cm}^{3}\right)$ & $\begin{array}{l}\text { Specific volume } \\
\qquad\left(\mathrm{gm} / \mathrm{cm}^{3}\right)\end{array}$ \\
\hline \multicolumn{5}{|c|}{ Pan bread } \\
\hline control & 18.1 & 176.3 & 266.5 & 1.51 \\
\hline $10 \%$ & 18.4 & 179.8 & 281.0 & 1.56 \\
\hline $20 \%$ & 18.7 & 183.1 & 295.5 & 1.61 \\
\hline $30 \%$ & 18.9 & 188.2 & 309.6 & 1.65 \\
\hline $40 \%$ & 16.6 & 221.4 & 260.2 & 1.18 \\
\hline $50 \%$ & 15.1 & 229.5 & 255.5 & 1.11 \\
\hline \multicolumn{5}{|c|}{ Pies } \\
\hline control & 3.4 & 86.83 & 99.5 & 1.15 \\
\hline $10 \%$ & 3.8 & 93.21 & 104.5 & 1.12 \\
\hline $20 \%$ & 4.6 & 100.0 & 109.0 & 1.09 \\
\hline $30 \%$ & 5.0 & 111.39 & 112.5 & 1.01 \\
\hline $40 \%$ & 3.3 & 100.6 & 96.0 & 0.95 \\
\hline $50 \%$ & 3.3 & 112.5 & 88.5 & 0.79 \\
\hline
\end{tabular}


Table 9. Sensory Characteristics of pan bread and pies Properties, in the same column, within the same letter are not significantly different at 0.05 levels.

\begin{tabular}{|c|c|c|c|c|c|c|c|c|c|c|}
\hline \multirow{2}{*}{$\begin{array}{l}\text { Date syrup } \\
\text { (dibs) \% }\end{array}$} & \multicolumn{4}{|c|}{ External characteristics } & \multicolumn{5}{|c|}{ Internal characteristics } & \multirow{2}{*}{$\begin{array}{c}\text { Overall } \\
\text { acceptability }\end{array}$} \\
\hline & Symmetry & $\begin{array}{c}\text { General } \\
\text { appearance }\end{array}$ & $\begin{array}{l}\text { Crust } \\
\text { color }\end{array}$ & Volume & $\begin{array}{l}\text { Crumb } \\
\text { color }\end{array}$ & $\begin{array}{c}\text { Crumb } \\
\text { grain }\end{array}$ & Texture & Taste & Odor & \\
\hline $\begin{array}{c}\text { Pan bread } \\
\text { Control }\end{array}$ & $4.5^{\mathrm{a}}$ & $4.5^{\mathrm{a}}$ & $9.0^{\mathrm{ab}}$ & $9.5^{\mathrm{a}}$ & $9.5^{\mathrm{a}}$ & $19.0^{\mathrm{ab}}$ & $14.5^{\mathrm{a}}$ & $14.0^{\mathrm{a}}$ & $9.0^{\mathrm{ab}}$ & $93.5^{\mathrm{a}}$ \\
\hline $10 \%$ & $4.5^{\mathrm{a}}$ & $4.5^{\mathrm{a}}$ & $9.0^{a b}$ & $9.0^{\mathrm{ab}}$ & $9.0^{\mathrm{ab}}$ & $19.5^{\mathrm{a}}$ & $14.5^{\mathrm{a}}$ & $14.0^{\mathrm{a}}$ & $9.0^{\mathrm{ab}}$ & 93. ${ }^{\mathrm{ab}}$ \\
\hline $20 \%$ & $4.0^{\mathrm{ab}}$ & $4.5^{\mathrm{a}}$ & $9.0^{\mathrm{ab}}$ & $9.0^{\mathrm{ab}}$ & $9.0^{\mathrm{ab}}$ & $19.5^{\mathrm{a}}$ & $14.5^{\mathrm{a}}$ & $14.0^{\mathrm{a}}$ & $9.0^{\mathrm{ab}}$ & $92.5 b^{b}$ \\
\hline $30 \%$ & $4.0^{\mathrm{ab}}$ & $4.0^{\mathrm{ab}}$ & $8.0^{\mathrm{bc}}$ & $8.5^{\mathrm{b}}$ & $8.0^{\mathrm{bc}}$ & $18.5^{\mathrm{b}}$ & $14.5^{\mathrm{a}}$ & $13.0^{\mathrm{b}}$ & $8.5^{b}$ & $87.5^{\mathrm{d}}$ \\
\hline $40 \%$ & $4.0^{\mathrm{ab}}$ & $4.0^{\mathrm{ab}}$ & $7.5^{c}$ & $8.5^{\mathrm{b}}$ & $8.0^{\mathrm{bc}}$ & $18.0^{\mathrm{bc}}$ & $13.5^{\mathrm{b}}$ & $12.5^{\mathrm{bc}}$ & $8.5^{\mathrm{b}}$ & $84.5^{f}$ \\
\hline $50 \%$ & $3.5^{b}$ & $3.5^{\mathrm{b}}$ & $7.0^{\text {cd }}$ & $8^{.0 \mathrm{bc}}$ & $7.0^{\text {cd }}$ & $16.5^{\mathrm{d}}$ & $13.5^{\mathrm{b}}$ & $12.5^{\mathrm{bc}}$ & $8.5^{b}$ & $80.0^{\mathrm{h}}$ \\
\hline Pies control & $4.5^{\mathrm{a}}$ & $4.5^{\mathrm{a}}$ & $9.5^{\mathrm{a}}$ & $9.5^{\mathrm{a}}$ & $9.5^{\mathrm{a}}$ & $18.5^{\mathrm{b}}$ & $14.5^{\mathrm{a}}$ & $14.0^{\mathrm{a}}$ & $9.5^{\mathrm{a}}$ & $94.0^{\mathrm{a}}$ \\
\hline $10 \%$ & $4.5^{\mathrm{a}}$ & $4.5^{\mathrm{a}}$ & $9.5^{\mathrm{a}}$ & $9.0^{\mathrm{ab}}$ & $9.0^{\mathrm{ab}}$ & $18.0^{\mathrm{bc}}$ & $14.5^{\mathrm{a}}$ & $13.5^{\mathrm{ab}}$ & $9.0^{\mathrm{ab}}$ & $91.5^{\mathrm{bc}}$ \\
\hline $20 \%$ & $4.5^{\mathrm{a}}$ & $4.0^{a b}$ & $8.5^{b}$ & $8.5^{b}$ & $8.5^{\mathrm{b}}$ & $17.5^{c}$ & $13.5^{\mathrm{b}}$ & $13.5^{\mathrm{ab}}$ & $9.0^{\mathrm{ab}}$ & $87.5^{\text {cd }}$ \\
\hline $30 \%$ & $4.0^{a b}$ & $4.0^{a b}$ & $8.0^{\mathrm{bc}}$ & $8.5^{b}$ & $8.5^{b}$ & $17.5^{\mathrm{c}}$ & $13.0^{\mathrm{bc}}$ & $12.5^{\mathrm{bc}}$ & $8.5^{b}$ & $84.5^{f}$ \\
\hline $40 \%$ & $4.0^{\mathrm{ab}}$ & $4.0^{a b}$ & $7.5^{c}$ & $7.5^{c}$ & $7.5^{c}$ & $16.5^{\mathrm{d}}$ & $12.0^{\mathrm{d}}$ & $11.5^{\mathrm{d}}$ & $8.5^{b}$ & $79.0^{\mathrm{h}}$ \\
\hline $50 \%$ & $3.5^{\mathrm{b}}$ & $3.5^{\mathrm{b}}$ & $6.5^{\mathrm{d}}$ & $7.0^{\mathrm{cd}}$ & $7.0^{\mathrm{cd}}$ & $16.0^{\text {de }}$ & $11.5^{\mathrm{de}}$ & $11.0^{\mathrm{de}}$ & $8.5^{\mathrm{b}}$ & $74.5^{i}$ \\
\hline
\end{tabular}


Table 10. Compressibility of pan bread processed with different level of date syrup (dibs) during storage at $25 \mathrm{c}^{\circ}$

\begin{tabular}{|c|c|c|c|c|c|c|c|}
\hline \multirow{2}{*}{$\begin{array}{l}\text { Date syrup } \\
\text { (dibis)\% }\end{array}$} & \multicolumn{7}{|c|}{ Storage period (days) } \\
\hline & zero & & 1 & & 2 & & 3 \\
\hline \multicolumn{8}{|c|}{ Compressibility } \\
\hline & Value & Value & $\%$ Change & Value & $\%$ Change & Value & $\%$ Change \\
\hline Control & 27.7 & 24.5 & -11.50 & 22.6 & -18.40 & 18.8 & -32.21 \\
\hline $10 \%$ & 36.8 & 34.9 & -5.16 & 31.8 & -13.51 & 29.5 & -19.80 \\
\hline $20 \%$ & 36.9 & 33.8 & -8.40 & 31.8 & -13.82 & 29.1 & -21.14 \\
\hline $30 \%$ & 35.4 & 32.6 & -7.91 & 29.9 & -15.53 & 28.8 & -18.62 \\
\hline $40 \%$ & 31.3 & 28.3 & -9.64 & 26.6 & -15.01 & 24.9 & -20.24 \\
\hline $50 \%$ & 30.6 & 27.1 & -11.44 & 25.4 & -16.99 & 23.6 & -22.87 \\
\hline
\end{tabular}

Table 11. Compressibility of pies processed With different levels of date syrup (dibis) during storage at $25^{\circ} \mathrm{C}$.

\begin{tabular}{|c|c|c|c|c|c|c|c|}
\hline \multirow{2}{*}{$\begin{array}{c}\text { Date syrup } \\
\text { (dibs)\% }\end{array}$} & \multicolumn{6}{|c|}{ Storage period (days) } \\
\cline { 2 - 8 } & Zero & \multicolumn{2}{|c|}{1} & \multicolumn{2}{c|}{2} & \multicolumn{2}{c|}{3} \\
\hline \multirow{2}{*}{} & Value & Value & $\%$ Change & Value & $\%$ Change & Value & $\%$ Change \\
\hline \multirow{2}{*}{ Control } & 24.6 & 22.6 & -8.1 & 20.3 & -17.5 & 18.1 & -23.6 \\
\hline $10 \%$ & 28.8 & 27.1 & -5.9 & 25.0 & -13.2 & 23.8 & -17.4 \\
\hline $20 \%$ & 28.7 & 26.2 & -8.7 & 25.3 & -11.8 & 23.8 & -17.1 \\
\hline $30 \%$ & 28.1 & 25.4 & -9.6 & 24.1 & -14.2 & 22.9 & -18.5 \\
\hline $40 \%$ & 26.8 & 23.7 & -11.6 & 21.6 & -19.4 & 21.0 & -21.6 \\
\hline $50 \%$ & 26.1 & 22.4 & -14.2 & 20.4 & -21.8 & 20.1 & 22.9 \\
\hline
\end{tabular}




\section{REFERENCES}

1. AACC. 2004. Approval Method of American Association of cereal Chemists Publ. by American Association of Cereal Chemists, In. St. Paul. Minnesota, USA.

2. Ahmed, J. and H.S. Ramaswamy. 2006. Physico-chemical properties of commercial date pastes (Phoenix dactylifera). Journal of Food Engineering, 76: 348-352.

3. Al-Farsi, M., C. Alasalvar, , K. Al-Shoaily, M. Al-Amry and F. Al-Rawahy. 2007. Composition and functional characteristics of dates' syrups, and their byproducts. Food Chemistry, 104: 943-947.

4. Al-Hooti, S.N., J.S. Sidhu, J.M. and Al-Saqer, A. Al-Othman. 2002.Chemical composition and quality of date syrup as affected by pectinase / cellulase enzyme treatment. Food Chemistry, 79: 215-220.

5. AL -Saidy, M.A., AL-Dujaili,K, A. and Majeed, A.M.1999. Evaluation of date syrup as substitute for sugar in bread making. Iraqi J. Biol. Sci., 13: 93-107.

6. Al-Zubaydi , A.H. ,Al-Kaissi , A.A. , Shaker , K.A. ,and Hamel, S.M. 2003. Use of date syrup in breade making . Cereal Chem. . 60:56-58.

7. Awan.J.A. and S Farkhanda. 1999. Dates and date products Uni -Tech. Communication, 498-B, Peoples Colony, Faislabad, Pakistan.

8. Azza, A.A. 1997. The influence of various sugars on dough and bread properties .Cereal Chem., 28:463.

9. Bedeir, S.H. 2004. Addition of gluten, pentosans, ascorbic acid, and milk casein to wheat flour to produce a high quality bakery products. Ph.D.Thesis, Dept., Fac. of Agric. Banha Univ. Egypt.

10. Biglari, F., A.,. Alkarkhi, and A.M. Easa. 2009. Cluster analysis of antioxidant compounds in dates (Phoenix dactylifera): Effect of long-term cold storage. Food Chemistry, 112: 998-1001.

11. Chaiya, Y., Q. , and Bongsa, H. 2011. Antioxidant activity and phenolic compounds of 112 traditional Chinese medicinal plants associated with anticancer. Life Sciences, 74: 2157-2184.

12. Hussin, A.A. 2008. Antioxidant activity of Bahraini date palm (Phoenix dactylifera L.) fruits of various cultivars. International Journal of Food Science and Technology, 43(6): 1033-1040. 
13. FAO. 2007. Food and Agriculture Organization of the United Nations. Statistical Databases. Production Yearbook. Top ten dates Producers-(2007). Available online at : http : faostat.fao.org.

14. Iqbal, M., I.M. Munir and M. Niamatullah. 2011. Physico-Chemical characteristics of date palm (Phoenix dactylifera L.) cultivars at various maturity stages under environmental conditions of Dera Ismail Khan. J. Agric. Res., 49(2): 24.

15. Kitterman, J.S. and Barmore,M.A. 1999. Protein, ash, viscosity, and damaged starch relation in the sedimentation test. Cereal chem. 46: 281- 286.

16. Nedif, A.M., P. Navarro and P.E. Alvarez. 2011. Changes in chemical composition and nutritional quality grilled sardine (Clupea pilchardus) produced by frozen storage and microwave heating. J. Sci. of Food and Agric., 75(1): 125-132.

17. Sidhu, J.S., J.M. Al-Saqer, S.N. Al-Hooti and A. Al-Othman. 2003. Quality of pan bread made by replacing sucrose with date syrup produced by using pectinase / cellulose enzymes. Plant Foods for Human Nutrition,58: 1-8.

18. Snedecor, G. and W. Cochran. 1980. Statistical Methods, 7th ed., Iowa State University Press, Ames., Iowa, USA .

19. Spies, R. D. and Hoseny, R.C. 1982. Effect of sugar on starch gelatinization. Cereal Chem., 59:128-131

20. Ziemke, W.H. 1977. Raisin and raisin products for the baking industry. Bakers Dig. 51:26-29. 


\title{
تقييم خبز القو الب و الفطائر المصنعة باستخذام الاحلال الجزئى لثراب البلح (الدبس)
}

\author{
صلاح حمزة محمد بلير \\ معهُ بحوت تكنولوجيا الاغذيه - مركز البحوث الزراعية - الجيزة - مصر
}

يتميز شراب البلح بكونه مصدر ممتاز للسكريات المختزلة كالجلوكوز و الفركتوز والنى

تمثل أكثر من •^^\% من السكريات المختزلة بالاضافة إلى الألياف و المعادن ويزيد من القيمة الغذائية للأغذية المدعمة به ـ و الهدف من تلك الدراسة تقليل الفاقد من محصول البلح وذلك باعداده وحفظه

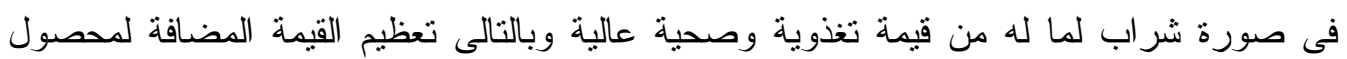
البلح المنتج فى مصر و اضافة تلك القيمة للاخل القومى ـ ولذلك فقد نم اجر اءهذا البحث لدر اسة تأثير

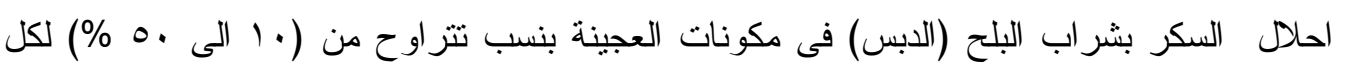
من خبز القوالب و الفطائر المصنعة بالطريقة المستقيمة .

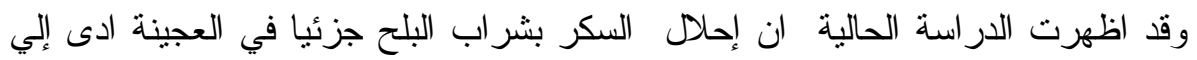

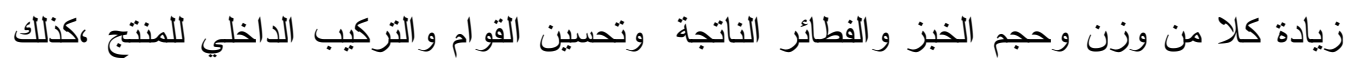

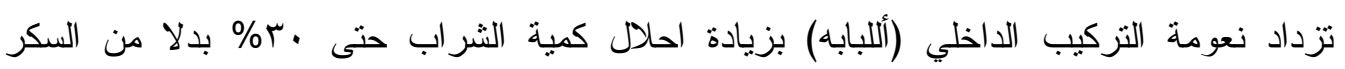

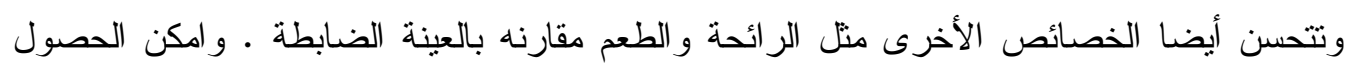

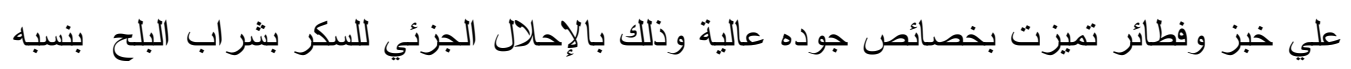

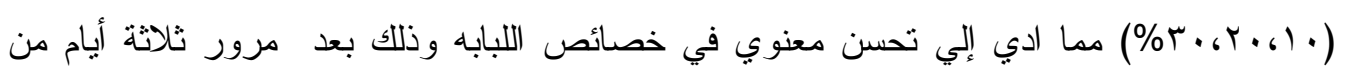

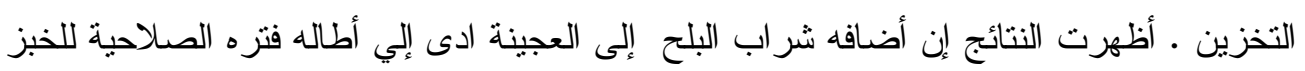

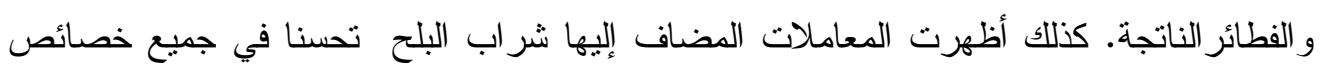
الجودة ماعدا لون اللبابه والذي يتأثز مباشره بنوعيه وصنف شراب البلح المستخدم في الاحلال وكذلك زيادة كميه الغاز الناتجة ،وتقلل من حدوث الجلتته (إعادة البللورة للنشا) مما كان لهانه تأثير

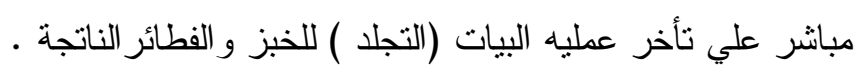

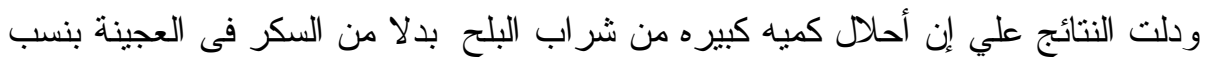
تصل الى (• ع، •0\%) له تأثير سلبي علي كميه الغاز المنتجة وتزيد من لزوجه العجينه . 